\title{
Ventilation and Haemodynamic Indicators in Spontaneously Breathing Pigs under General Anaesthesia
}

\author{
Jiří Kobr ${ }^{1}$, Vilém Kuntscher², Vladislav Třeška², Jiří Moláček², Václav Vobruba ${ }^{3}$, \\ Jiří Fremuth ${ }^{1}$ \\ ${ }^{1}$ Charles University in Prague, Faculty of Medicine in Pilsen and Department of Paediatrics - Paediatric \\ Intensive Care Unit, Faculty Hospital in Pilsen \\ ${ }^{2}$ Charles University in Prague, Faculty of Medicine in Pilsen and Department of Surgery, Faculty Hospital \\ in Pilsen \\ ${ }^{3}$ Charles University in Prague, First Faculty of Medicine and Department of Paediatrics - PICU, \\ General Faculty Hospital in Prague \\ Received December 17, 2008 \\ Accepted June 30, 2009
}

\begin{abstract}
The aim of this study was to obtain ventilation and haemodynamic data of healthy piglets under general anaesthesia for future patho-physiological experimental studies. A total of 34 domestic piglets of the Czech Black Pied (Přšstice) breed were used in the study. The animals (male to female ratio $8: 9$ ) were six weeks old and their average body mass was $22 \mathrm{~kg}$.

A general anaesthetic (fentanyl and azaperon) was introduced via a pulmonary artery catheter and the spontaneously breathing animals were monitored for $60 \mathrm{~min}$. Cardiac output and haemodynamic indicators were established using intermittent pulmonary artery thermodilution. Blood gas data were deduced using fan dynamic parameters of ventilation and ventilation indices.

The study yielded reliable data of dynamic lung indicators $(p<0.05)$; e.g. the tidal volume $6.00 \pm 0.82 \mathrm{ml} / \mathrm{kg}$, hypoxemic index $350.47 \pm 42.50 \mathrm{mmHg}$, lung compliance $0.63 \pm 0.12$ $\mathrm{ml} / \mathrm{cmH}_{2} \mathrm{O} / \mathrm{kg}$, and haemodynamic indicators $(p<0.01)$ such as cardiac output $2.12 \pm 0.75 \mathrm{l} / \mathrm{min}$, pulmonary vascular resistance $3.92 \pm 0.52$ and systemic vascular resistance $15.8 \pm 6.81$ Woods units.

Reliable data regarding lung dynamics, cardiac output, preload and afterload of both heart ventricles in spontaneously breathing healthy piglets under general anaesthesia were achieved.
\end{abstract}

Cardiac output, general anaesthesia, piglets, model

The aim of the present study was to create an experimental animal model for the study of ventilation and haemodynamic indicators in spontaneously breathing healthy pigs under general anaesthesia. The study was based on our previous experimental work with a surgical focus (Treska et al. 2002; 2003). For anaesthesia, we used a single dose of fentanyl. Our experimental and clinical experience confirms the information in the scientific literature that a single dose of fentanyl at $3.0 \mu \mathrm{g} / \mathrm{kg}$ minimally affects blood circulation (Hamon et al. 1995). Dynamic pulmonary indices in spontaneously breathing animals were calculated based on the data measured after a transitional connection of experimental piglets to the respiratory device. Systemic haemodynamic data and cardiac output were obtained invasively, using pulmonary artery thermodilution (PCA).

The concept of our study is original in that it monitors haemodynamic and lung indices of spontaneously breathing animals during general anaesthesia. Such representative data may be applied in further experimental studies.

\section{Materials and Methods}

The study was carried out with the approval of the multidisciplinary ethics committee, in accordance with $\$ 12$ of Decree No. 311/97 Dig. "The Act on protection and using of the experimental animals", at the accredited Experimental Centre of the Charles University in Prague, Faculty of Medicine in Pilsen.

Address for correspondence:

Doc. MUDr. Jiří Kobr, Ph.D.

Charles University in Prague

Faculty of Medicine in Pilsen

Department of Paediatrics-PICU, Faculty Hospital

Alej Svobody 80, 30460 Plzen, Czech Republic 
Experimental model

Thirty-four clinically healthy domestic piglets (Czech Black Pied (Přeštice) piglets) were randomly selected from a controlled programme (breeding farm in Přeštice; gene reserve; granulated feed type A1). All piglets (8 males and 9 females) were six weeks old with an average body mass of $22 \mathrm{~kg}$ (range $18-27 \mathrm{~kg}$ ).

Animal preparation

Following pre-medication with intramuscularly administered atropine $0.05 \mathrm{mg} / \mathrm{kg}$ (Atropin; HoechstBiotika, Slovakia) and azaperon $4.0 \mathrm{mg} / \mathrm{kg}$ (Stresnil; Janssen Pharmaceutica N.V., Belgium), peripheral venous access was gained via a cannula inserted into the piglet's auricle. Thiopental $10.0 \mathrm{mg} / \mathrm{kg}$ (Thiopental, VUAB Pharma, Czech Republic) was administered intravenously and tracheal intubation was performed with a cannula (ID $5.0 \mathrm{~mm}$ diameter) and an occlusive cuff (Kendall, Czech Republic). General anaesthesia was maintained using an intravenous combination of fentanyl $3.0 \mu \mathrm{g} / \mathrm{kg}$ (Fentanyl; Hexal AG, Germany), and azaperon $8.0 \mathrm{mg} / \mathrm{kg}$ (Jacson et al. 2007; Hodgkinson 2007). After cannulation of the internal jugular vein with a sheath (Arrow $5 \mathrm{~F}$; International CR, Germany), a right side cardiac catheterization was performed using a modified Swan-Ganz type thermodilution catheter (4 F; Cook, Denmark). Correct positioning of the catheter within the pulmonary artery was ensured using ultrasound navigation. Pressure curves were observed on a monitor (Life Scope 9, Nihon Kohden, Japan). Crystalloid infusions (Ringer; Infusia, Czech Republic) were administered via an infusion pump at $2.5 \mathrm{ml} / \mathrm{kg}$ per hour. Under general anaesthesia an arterial line was introduced into the femoral artery using Seldinger's method (catheter: 22G, Arrow International CR, Germany), samples to the arterial blood and monitoring pressure. Systemic arterial pressure values were recorded using a Life Scope 9 monitor (Nihon Kohden, Japan). Pulse oxymetry values were ascertained from a probe attached to the pig's auricle (Knotek et al. 1995).

Protocol of study

In the study, 34 spontaneously breathing domestic piglets were used. Dynamic lung mechanics, cardiac output and haemodynamic indices were measured in each animal following the invasive procedures (time- 0 ) and at 60 $\min ($ time-1).

Adjustments were made to servo ventilator settings (Elema $900 \mathrm{C}$, Siemens, Germany) such that spontaneous ventilation and inhaled air $\left(\mathrm{FiO}_{2} 0.21\right)$. Recorded data included respiratory rate (RR; breath/min), inspiratory pressure $\left(\mathrm{P}_{\text {insp }} ; \mathrm{cmH}_{2} \mathrm{O}\right)$, peak inspiration pressure $\left(\mathrm{PIP} ; \mathrm{cmH}_{2} \mathrm{O}\right)$, mean airway pressure $\left(\mathrm{P}_{\text {aw }} ; \mathrm{cmH}_{2} \mathrm{O}\right)$, expiration tidal volume $\left(\mathrm{VT}_{\text {exp }} ; \mathrm{ml} / \mathrm{kg}\right)$, end-tidal carbon dioxide $\left(\mathrm{EtCO}_{2} ; \mathrm{kPa}\right)$ and minute respiratory volume (MV; $\left.\mathrm{ml} / \mathrm{min}\right)$. In arterial blood, acid-basic balance and current blood gas tensions were determined to calculate the indices: Alveolar-arterial oxygen tension difference $\left(\mathrm{AaDO}_{2} ; \mathrm{kPa}\right)$, arterio-alveolar oxygen tension difference $\left(\mathrm{a} / \mathrm{ADO}_{2}\right.$; $\mathrm{kPa})$, oxygenation index $\left[\mathrm{OI}=\left(\mathrm{P}_{\mathrm{aw}} \times \mathrm{FiO}_{2}\right) \times 100 / \mathrm{PaO}_{2} ;-\right)$, hypoxemic index $\left(\mathrm{PaO}_{2} / \mathrm{FiO}_{2} ;-\right)$, dead space-to-tidal volume ratio $\left(\mathrm{V}_{\mathrm{D}} / \mathrm{V}_{\mathrm{T}} ; \%\right)$, ventilation index $\left(\mathrm{VI}=\mathrm{P}_{\mathrm{aw}} \times \mathrm{BR} ;-\right)$, total dynamic lung compliance $\left(\mathrm{C}_{\mathrm{dyn}} ; \mathrm{ml} / \mathrm{cmH}_{2} \mathrm{O} / \mathrm{kg}\right)$ and airway dynamic flow resistance $\left(\mathrm{R}_{\mathrm{aw}} ; \mathrm{cmH}_{2} \mathrm{O} / \mathrm{l} / \mathrm{s}\right)$.

The blood systolic, mean arterial and diastolic blood pressure $\left(\mathrm{BP}_{\text {syst }}, \mathrm{MAP}, \mathrm{BP}_{\text {diast }} ; \mathrm{mmHg}\right)$ was monitored using an arterial catheter during the course of the experiment.

Cardiac output was measured using an intermittent thermo dilution method (Takano et al. 1997) with a pulmonary artery catheter. Temperature sensor at the end of the catheter measured the blood temperature. The average temperature of $38.9^{\circ} \mathrm{C}$ in the pulmonary artery of animals ensured adequate thermal difference in the test solution $(0.9 \mathrm{M} \mathrm{NaCl})$ maintained at room temperature of $21{ }^{\circ} \mathrm{C}$. During the measurement, $2 \mathrm{ml}$ of test solution were injected within two seconds to the proximal lumen of the pulmonary artery catheter. Haemodynamic data were directly ascertained from a monitor (Nihon Kohden, Japan) or derivative. The average value of 5 consecutive measurements taken at intervals of $30 \mathrm{~s}$ was directly measured: pulse heart rate (HR; beats/min), stroke volume $(\mathrm{SV} ; \mathrm{ml} / \mathrm{beats})$, cardiac output $(\mathrm{CO} ; 1 / \mathrm{min})$ and the mean values of pressures: central venous / right atrial (CVP/ RAP; $\left.\mathrm{cmH}_{2} \mathrm{O}\right)$, right ventricular $\left(\mathrm{RVP} ; \mathrm{cmH}_{2} \mathrm{O}\right)$, pulmonary artery $\left(\mathrm{PAP} ; \mathrm{cmH}_{2} \mathrm{O}\right)$ and pulmonary artery occlusive pressure ( $\left.\mathrm{P}^{2} \mathrm{AOP} ; \mathrm{cmH}_{2} \mathrm{O}\right)$. Derivative values were the differences of mean arterial and venous system pressures (MAP-CVP; $\left.\mathrm{cmH}_{2} \mathrm{O}\right)$. To calculate the cardiac index $\left(\mathrm{CI}=\mathrm{CO} / \mathrm{BSA} ; 1 / \mathrm{min} / \mathrm{m}^{2}\right)$ it was necessary to establish the physical surface area of each piglet. To obtain the methodology of calculations in piglets we consulted the Department of Physiology of the Veterinary and Pharmaceutical University in Brno. The body surface area of each piglet was calculated using Meehe's formula $\left(\right.$ BSA piglet $=[0.087 \times$ body mass $\left.] / 0.66 ; \mathrm{m}^{2}\right)$. Veterinary medicine covers all the indicators of the metabolically active mass of the animal (Kleiber 1934). The metabolically active mass (MAM) of each animal was calculated using generally accepted Kleiber's formula (MAM $=0.75 \times$ body mass; $\mathrm{kg}$ ) (Painter 2005). The cardiac index may thus be derived using Meehe's $\left(\mathrm{CI}_{\mathrm{M}}\right)$ and Kleiber's calculations $\left(\mathrm{CI}_{\mathrm{K}}\right)$. The systemic vascular resistance $(\mathrm{SVR}=[\mathrm{MAP}-\mathrm{CVP}] / \mathrm{CO}$; Woods units $)$ and total pulmonary vascular resistance $(\mathrm{PVR}=[\mathrm{PAP}-\mathrm{PAoP}] / \mathrm{CO}$; Woods units) was calculated.

Statistical analysis

The obtained data were statistically analyzed by descriptive quantitative parametric analysis (mean, $95 \%$ CI of the mean, standard deviation) and qualitative non-parametric analysis (median, $95 \% \mathrm{CI}$ of the median, minimum, maximum, $1^{\text {st }} \mathrm{Q}, 3^{\text {rd }} \mathrm{Q}$ of IQR), paired $t$-test (Student) and non-paired $t$-test (Shapiro-Wilcoxon), linearity (linearfit), average (Anderson-Darling), and reproducibility (Bland et al. 1986). Data were analyzed using PC software (Analyse-it211 Software, Ltd.). The values are listed in the text and tables as mean and standard deviation (mean $\pm \mathrm{SD})$. Values at $P<0.05$ were considered significant. 
Completion of the experiment

Upon the completion of 60 min measurement (time-1), the animals were randomized to surgical procedures for subsequent experiments.

The experiment was terminated in accordance with the Helsinki Declaration of 2004. Potassium chloride cardioplegic solution (Infuse Thomas cum procain; Ardapharma, CZ) was administered into the right atrium of the experimental animals under general anaesthesia. The dead animal bodies were disposed of and incinerated according to the official regulations of the Czech Republic and European Union.

\section{Results}

Ventilation indicators

Ventilation data values of spontaneously breathing piglets had a high degree of reproduTable 1. Lung indicators and ventilation indexes $(n=68)$

\begin{tabular}{|l|c|c|c|c|c|}
\hline Indicators & Mean & SD & Median & IQR & Unit \\
\hline $\mathrm{RR}$ & 30 & 3.92 & 28 & 2.5 & breath/min \\
\hline $\mathrm{PIP}$ & 11.00 & 2.70 & 12 & 2.9 & $\mathrm{cmH}_{2} \mathrm{O}$ \\
\hline $\mathrm{P}_{\text {aw }}$ & 4.80 & 2.01 & 5.0 & 0.9 & $\mathrm{cmH}_{2} \mathrm{O}$ \\
\hline $\mathrm{VT}_{\text {exp }}$ & 6.00 & 0.82 & 6.0 & 1.0 & $\mathrm{ml} / \mathrm{kg}$ \\
\hline $\mathrm{MV}$ & 4.80 & 0.99 & 4.7 & 1.6 & $1 / \mathrm{min}$ \\
\hline $\mathrm{EtCO}_{2}$ & 5.10 & 0.67 & 5.0 & 1.2 & $\mathrm{kPa}$ \\
\hline $\mathrm{AaDO}_{2}$ & 1.69 & 0.89 & 1.5 & 0.2 & $\mathrm{kPa}$ \\
\hline $\mathrm{a} / \mathrm{ADO}_{2}$ & 0.82 & 0.17 & 0.8 & 0.04 & $\mathrm{kPa}$ \\
\hline $\mathrm{OI}^{\mathrm{PaO}} / \mathrm{FiO}_{2}$ & 350.47 & 42.50 & 360.5 & 16.8 & - \\
\hline $\mathrm{VI}$ & 22.86 & 5.37 & 23.0 & 2.4 & - \\
\hline $\mathrm{V}_{\mathrm{D}} / \mathrm{V}_{\mathrm{T}}$ & 22.25 & 8.95 & 21.6 & 1.6 & $\%$ \\
\hline $\mathrm{C}_{\text {dyn }}$ & 0.63 & 0.12 & 0.6 & 0.04 & $\mathrm{ml} / \mathrm{cmH}$ \\
\hline $\mathrm{R}_{\text {awe }}$ & 0.95 & 0.32 & 0.93 & 0.07 & $\mathrm{~cm} \mathrm{~m}_{2} \mathrm{O} / \mathrm{kg}$ \\
\hline
\end{tabular}
cibility between time- 0 and time- 1 $(p<0.001)$, average $(p=0.0026)$, agreement $0.95 \pm 0.02$ and with non-significant differences $(t$-test 0.083).

A summary of dynamic lung indicators and ventilation indexes are presented in Table 1 .

\section{Cardiac Output Data}

Cardiac output and haemodynamic data values in spontaneously breathing piglets had a high degree of reproducibility between time-0 and time- 1 $(p<0.001)$, average $(p=0.0047)$, agreement $0.92 \pm 0.05$, with nonsignificant differences ( $t$-test 1.05). Fig. 1 reflects the quality of the measurement of cardiac output.

At the beginning of the study the average values of the monitored indicators differed

\section{Normal Probability Plot}

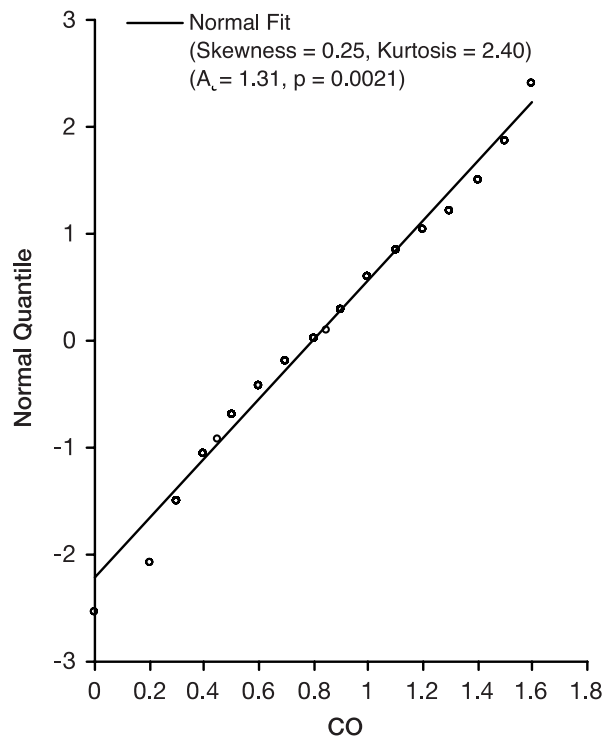
with only minimal significance $(p=$ 0.196). A summary of cardiac output and haemodynamics is presented in table 2 .

\section{Discussion}

There are many similarities between pigs and humans, which make the swine a valuable experimental model system for investigating a variety of scientific indicators. Of particular importance to the field of cardiopulmonary science is that despite some anatomic differences, the haemodynamics, respiratory and associated metabolic processes are similar in humans and pigs (Chandler et al. 1990; Phillips et al. 2006). Our animal model and the measurement results correspond to clinical

Fig. 1. Distribution of cardiac output values and the normal probability $(n=68)$

$\mathrm{CO}$ - cardiac output in $\mathrm{x}$-axis, normal quartile of the cardiac output in $\mathrm{y}$-axis 
Table 2. Cardiac output and haemodynamic indicators $(n=68)$

\begin{tabular}{|l|c|c|c|c|c|}
\hline Indicators & Mean & SD & Median & IQR & Units \\
\hline HR & 119 & 19.4 & 115 & 5.2 & beats/min \\
\hline CVP/RAP & 2.6 & 1.96 & 3.0 & 3.0 & $\mathrm{cmH}_{2} \mathrm{O}$ \\
\hline $\mathrm{BP}_{\text {syst }}$ & 97 & 14.60 & 96 & 3.0 & $\mathrm{mmHg}$ \\
\hline MAP & 76.5 & 10.46 & 75.7 & 9.4 & $\mathrm{mmHg}$ \\
\hline $\mathrm{BP}_{\text {diast }}$ & 66 & 7.08 & 64 & 8.3 & $\mathrm{mmHg}$ \\
\hline MAP-CVP & 72.16 & 2.98 & 71.5 & 2.3 & $\mathrm{cmH}_{2} \mathrm{O}$ \\
\hline RVP & 14.8 & 2.09 & 14.0 & 3.0 & $\mathrm{cmH}_{2} \mathrm{O}$ \\
\hline PAP & 16.2 & 2.11 & 16.5 & 2.6 & $\mathrm{cmH}_{2} \mathrm{O}$ \\
\hline PAoP & 9.8 & 2.28 & 9.0 & 4.0 & $\mathrm{cmH}_{2} \mathrm{O}$ \\
\hline SV & 18.0 & 2.51 & 17.6 & 1.7 & $\mathrm{ml} / \mathrm{beats}$ \\
\hline CO & 2.12 & 0.75 & 2.0 & 0.6 & $1 / \mathrm{min}^{2}$ \\
\hline $\mathrm{CI}_{\mathrm{M}}$ & 1.3 & 0.32 & 1.1 & 0.2 & $1 / \mathrm{min}^{2} / \mathrm{m}^{2}$ \\
\hline $\mathrm{CI}_{\mathrm{K}}$ & 0.8 & 0.02 & 0.8 & 0.01 & $1 / \mathrm{min}_{\mathrm{kg}}$ \\
\hline $\mathrm{SVR}$ & 15.8 & 6.81 & 15.0 & 5.4 & Woods units \\
\hline $\mathrm{PVR}$ & 3.92 & 0.52 & 3.7 & 0.3 & Woods units \\
\hline $\mathrm{T}_{\mathrm{C}}$ & 38.9 & 0.44 & 38.0 & 0.9 & ${ }^{\circ} \mathrm{C}$ \\
\hline
\end{tabular}

situations prior to general anesthesia with neuromuscular block for the operation (Treska et al. 2003; Kuntscher et al. 2007). Studies in newborn animals have similar goals (Gavianes et al. 2001, Juvik et al. 2007). The results of our study are partly comparable with the works of Pereira et al. (1996) and Phillips et al. (2006), which translated only some of the haemodynamic indicators of spontaneously breathing animals. The results of our study are partly comparable with the works of Pereira et al. (1996) and Phillips et al. (2006), which translated only some of the haemodynamic indicators of spontaneously breathing animals.

In our original study, we obtained a greater number and richer range of experimental data in spontaneously breathing animals during general anaesthesia.

We may conclude that the presented ventilation, cardiac output and haemodynamic data may be regarded as representative of piglets and can be used as a comparison for further experimental studies. The respiratory and cardiovascular systems of the experimental domestic pig are gut comparable to those of humans and are therefore ideal animal models for further pathophysiological studies.

\section{Ventilační a hemodynamické ukazatele u spontánně dýchajících prasat v celkové anestézii}

Cílem studie bylo získat ventilační a hemodynamická data zdravých selat v celkové anestézii pro účely budoucí patofyziologické experimentální studie. Do studie bylo zařazeno celkem 34 selat prasete domácího (plemeno přšstické černostrakaté). Zvíruta (poměr samců a samic 8:9) byla šest týdnů stará, průměrné hmotnosti $22 \mathrm{~kg}$.

V celkové narkóze (fentanyl a azaperon) byl spontánně dýchajícím zvíratům zaveden plicnicový katétr a zvírata byla monitorována 60 minut. Srdeční výdej a indikátory hemodynamiky byly měřeny intermitentní termodilucí plicnicovým katétrem. Data krevních plynů a dynamických ukazatelů ventilace byly použity k výpočtům ventilačních indexů.

Studie předložila relevantní data dynamických plicních $(p<0.05)$ a hemodynamických ukazatelů $(p<0.01)$, např. dechový objem $6.00 \pm 0.82 \mathrm{ml} / \mathrm{kg}$, hypoxémický index 350.47 $\pm 42.50 \mathrm{mmHg}$, plicní poddajnost $0.63 \pm 0.12 \mathrm{ml} / \mathrm{cmH} 2 \mathrm{O} / \mathrm{kg}$, srdeční výdej $2.12 \pm 0.75 \mathrm{l} /$ min, plicní cévní rezistence $3.92 \pm 0.52$ a systémová cévní rezistence $15.8 \pm 6.81$ Woodsovy jednotky. Získána byla kompletní data plicní dynamiky, srdečního výdeje, předtížení a dotížení obou srdečních komor u spontánně dýchajících zdravých selat v celkové anestézii.

\section{Acknowledgements}

The article was prepared with the support of the research intention Medical Faculty of the Charles University in Pilsen MSM0021620819 and grant IGA MZ ČR NR 7913-3/9594. Thanks to all members of research teams. 


\section{References}

Bland JM, Altman DG 1986: Statistical methods for assessing agreement between two methods of clinical measurement. Lancet 1: 307-310

Chandler CJ, Ong BY, Sitar DS 1990: Haemodynamic alteration in anaesthetized and acutely intoxicated newborn piglets. Br J Pharmacol 101: 227-231

Gavianes AWD, Vles JSH, von Siebenthal K, Reulen JP, Niemand FH, van Sprundel R, Biaco CE 2001: Electrocortical brain activity, cerebral haemodynamics and oxygenation during progressive hypotension in newborn piglets. Clin Neurophysiol 112: 52-59

Hamon I, Hascoët JM, Debbiche A, Vert P 1995: Effects of fentanyl administration on general and cerebral haemodynamics in sick newborn infants. Acta Paed 85: 361-365

Heltne JK, Farstad M, Lund T, Koller ME, Matre K, Rynning, SE, Husby P 2002: Determination of plasma volume in anaesthetized piglets using the carbon monoxide (CO) method. Lab Animals 36: 344-350

Hodgkinson O 2007: Practical sedation and anaesthesia in pigs. Practice 29: 34-39

Jacson PGG, Cockroft PD 2007: Analgesia, anaesthesia, and surgical procedures in the pig. In.: Handbook of Pig Medicine, Saunders Elsevier Co. 2007, pp. 230-233

Juvik E, Solligäd E, Brubakk AO, Brubakk AM 2007: Arterial air embolism after venous air infusion in newborn piglets. Acta Paed 90: 786-792

Kleiber M 1934: Body size and metabolism. Hilgarda 6: 315-353

Knotek Z 1995: The use of animals in the experimental work (Použití zvírat v experimentální práci), Brno, pp. $46-56$

Kuntscher V, Treska V, Racek J, Kobr J, Trefil, L, Hes O 2007: Does the administration of antioxidants as scavengers of reactive oxygen species in kindney transplantation really have sense? Bratisl Lek Listy 108: 385-387

Painter PR 2005: Supply-demand balance in outward-directed networks and Kleiber's law. Theor Biol Med Model; 2: 45 [Pub online 2005, Nov 10, doi> 10.1186/1742-4682-45]

Pereira CM, Tam YK, Coe JY, Olley PM, Collins-Nakai, RL 1996: Pharmacokinetic-pharmacodynamic modelling for captopril in healthy anaesthetized piglets. Biopharmaceutics \& Drug Disposition 17: 365-372

Phillips RA, Sloninger JA, Scansen B, West MJ, Burstow DJ, Bonagura JD, Muir W 2006: Cardiac output measurement in animals using the non-invasive USCOM device. Presented at the Veterinary Congress, Abstract, San Antonio, Texas, September 17-21

Takano JS 1997: Chapter 133 - Advanced haemodynamic monitoring: Pulmonary artery and left atrial catheterization. In: Levin DL, Morris FC. Essentials of Pediatric Intensive Care. $2^{\text {nd }}$ Edd., Churchill Livingstone Inc., pp.1234-1248

Třeška V, Kuntscher V, Hassman D, Kobr J, Racek J, Trefil L, Hes O, Reischig T 2002: Plasma and tissue levels of free oxygen radicals in recipients of kidneys from non-heart-beating donors: does recipient pre-treatment with antioxidant drugs make sense? An experimental study in pigs. Transplant Proc 34: 3060-3064

Třeška V, Kuntscher V, Moláček J, Kobr J, Racek J, Trefil L 2003: Can ischemia-reperfusion syndrome in transplanted kidneys procedure from non-heart-beating donors be influenced by adding selenium into the reperfusion solution? An experimental study. Transplant Proc 35: 3125-3127 
